A N N A L E S

UNIVERSITATIS MARIAE CURIE-SKŁODOWSKA

LUBLIN - POLONIA

VOL. XXXI, 4

SECTIO J

2018

Górnośląska Wyższa Szkoła Handlowa im. Wojciecha Korfantego. Wydział Zarządzania

\title{
MIROSŁAW HARCIAREK
}

ORCID: 0000-0003-1939-1868

miroslaw.harciarek@gmail.com

\section{Podstawowa jednostka przetwarzania informacji integrujaca poznanie, emocje i język}

Basic Unit of Information Processing Integrating Cognition, Emotions, and Language

\section{STRESZCZENIE}

W pracy podjęto problem istnienia jednostki poznawczej integrującej podstawowe procesy psychiczne: poznanie, emocje i język. W tym celu, inspirując się poglądami K. Pribrama i R. Llinasa, zaproponowano wykorzystanie w psychologii koncepcji podstawowej jednostki przetwarzania informacji (logonu), która ma postać matematycznego wzoru opracowanego przez D. Gabora. Wskazano na argumenty przemawiające za istnieniem takiej jednostki w psychice oraz omówiono jej wartość dla psychologii, nawiązując do koncepcji okna uwagowego, teorii postaci (Gestalt) oraz równoważenia struktur poznawczych według J. Piageta.

Słowa kluczowe: jednostka poznawcza; logon; poznanie; emocje; język; okno uwagowe; równoważenie struktur poznawczych; teoria komunikacji

\section{WPROWADZENIE}

O tym, że istnieje ścisły związek między poznaniem a emocjami i językiem, nie trzeba nikogo przekonywać, problem dotyczy tylko charakteru tej relacji. Jaki związek można zatem postulować między poznaniem a emocjami oraz emocjami a językiem lub poznaniem a językiem (por. Wittgenstein 1997)? Czy istnieje jednostka łącząca te procesy? Udzielenie odpowiedzi na te pytania jest podstawowym celem rozważań i analiz zawartych w niniejszym opracowaniu. Przede wszystkim w tym szkicu teoretycznym chodzi o zwrócenie uwagi na już istniejącą 
podstawową propozycję przetwarzania informacji, która - jak się wydaje - integruje poznanie, emocje i język, a jest ufundowana na matematycznej teorii komunikacji D. Gabora (1946, s. 429-457). Na prowadzone tu rozważania wpływ mają poglądy K. Pribrama (2013), R.R. Llinasa (2011) i innych autorów, którzy opowiadają się za istnieniem podstawowej jednostki poznawczej.

\section{CZY ISTNIEJE PODSTAWOWA JEDNOSTKA POZNAWCZA?}

Relacja między emocjami a poznaniem przypomina relację między energią jako popędem a informacją jako treścią. Związek emocji z poznaniem jest oczywisty, udowadniają to zarówno codzienne doświadczenia, jak i liczne badania, a także psychologia poznawcza, która wyrosła na podłożu tej relacji i przyjęła z jednej strony prymat poznania, a z drugiej obecność pobudzenia podlegającego interpretacji poznawczej, co nie tylko ma wyjaśniać nasze życie wewnętrzne, ale też stało się uznanym fundamentem psychoterapii poznawczej.

Przyjmując za oczywisty pogląd, że nasze życie psychiczne jest względnie zintegrowaną całością, jednocześnie zakładamy, że istnieje jakaś jego podstawowa struktura, pewien wzór czy schemat wyznaczający wzajemne relacje między jego składowymi (np. między emocjami a poznaniem). Inaczej mówiąc, wydaje się, że jest koniecznością, aby psychologia dysponowała podstawową jednostką poznawczą, której wzorem jest np. TOTE czy Gestalt, istotne są poza tym koncepcja monady Leibniza czy ,atom psychiki”, na jaki wskazywał W. Wundt. Coraz większa ilość badań dotyczących pracy mózgu oraz rozwój neuropsychologii i kognitywistyki nie tyle potwierdzają ścisły związek emocji z poznaniem, co wręcz zmuszają do jakiegoś modelu ich integracji i rozumienia wspomnianych kategorii jako jednej funkcjonalnej całości. W efekcie powstaje problem znalezienia podstawowej jednostki, która mogłaby być kontynuacją i rozwinięciem dotychczasowych osiągnięć psychologii (jak np. jednostki TOTE czy Gestalt), ale która by dotychczasowe propozycje wyjaśniła i doprecyzowała. Wszak jednostka TOTE, zaproponowana przez G.A. Millera, E. Galantera i K.H. Pribrama (1980), oparta na koncepcji sprzężenia zwrotnego, jest trudna do operacjonalizacji. Mimo że sami autorzy, aby wyjaśnić dynamikę psychiki, wprowadzili dwie trafne kategorie, z których jedna stanowi „plany” mogące uchodzić za pomieszczające emocje, a druga to „obrazy” obejmujące treści, to jednak nie ma w tej propozycji opisu dokładniejszej relacji między emocjami (planami) a poznaniem (obrazami), choć autorzy próbują uporać się z tym zagadnieniem. Z kolei starsza koncepcja jednostki Gestalt nie precyzuje dostatecznie zadowalająco kategorii figury i tła oraz zależności między nimi na tyle, aby można było ustalić relację emocji do poznania (nie wyjaśnia, co warunkuje i ogranicza figurę i tło). W tej koncepcji emocje mogą być raz ttem, a innym razem relacją między figura a ttem, natomiast w przypadku bardzo silnej emocji mogą być tylko figurą. Wygląda to tak, jakby 
struktura formalna Gestaltu „ukrywała” w sobie emocje jako potencjalne swoje właściwości i jedynie w pewnych sytuacjach je ujawniała. Jeśli idzie o antynomię figury i tła, to jej odpowiednikiem w odniesieniu do koncepcji TOTE może być antynomia obrazu i planu. Tak czy inaczej w psychologii konieczna jest koncepcja, która by pogłębiała i precyzowała istniejące już modele jednostek poznawczych, a zwłaszcza wyjaśniłaby relację emocji do poznania i odwrotnie. Wydaje się, że poszukiwanie takiej jednostki jest potrzebne, a dotychczasowe zafiksowanie się psychologów i kognitywistów na próbach zdefiniowania podstawowej informacji psychicznej rozumianej jako bit należy przezwyciężyć.

Warto w tym miejscu ponownie zauważyć, że niezależnie od powyższych refleksji dotyczących jednostki poznawczej praktyka psychologiczna i neuropsychologiczna właściwie wymusza jej istnienie. Taką jednostką, która została wprowadzona do psychologii z konieczności i niejako weszła do niej bocznymi drzwiami, zdobywając prawo obywatelstwa, jest okno uwagowe (trwające około 100-550 ms) (por. Senderecka 2016, s. 391-411). Jak się okazuje, jest ono konieczne do wyjaśnienia przebiegów EEG i jego składowych, czyli struktury czasowej i synchronizacji potencjałów czynnościowych kory mózgowej. Pojęcie to, ze względu na stosunkowo wąskie funkcje teoretyczne, wymaga szerszego i głębszego wyjaśnienia, czyli dokładniejszej interpretacji, niż ma to miejsce obecnie. Trudno zaakceptować sytuację, kiedy w oderwaniu od już istniejącej wiedzy wprowadza się do psychologii termin niejako spoza istniejących teorii poznania i bez odniesień do nich. Taka sytuacja raczej oddala nas od zrozumienia procesów poznawczych. Istotne jest jednak to, aby uświadomić sobie, że konieczność wprowadzenia pojęcia okna uwagowego do psychologii wyraźnie wskazuje nie tylko na prawdopodobne istnienie podstawowej jednostki poznawczej, ale też na to, jak bardzo ważną i pilną sprawą jest refleksja nad nią oraz jej badanie. Sprawa jest tym bardziej paląca, że okno uwagowe dotyczy jednego z podstawowych procesów psychicznych, czyli uwagi.

Podobne zagadnienie, dotyczące okna jednoczesności, przedstawił w swoich pracach E. Pöppel (1989, s. 162), określając je wieloma terminami: „horyzontem jednoczesności”, „trwaniem”, „mechanizmem integracyjnym, który zespala”, „okresem oscylacji w mózgu”, „trzysekundowym oknem teraz”, ,cegiełkami czterdziestomilisekundowymi i kilkusekundowymi” (Pöppel, Edingshaus 1998, s. 9). Analizy prowadzone przez tego autora również wskazują na teoretyczne i praktyczne znaczenie okna uwagowego, a tym samym na konieczność refleksji i prowadzenia badań nad podstawową jednostką poznawczą.

Nie kontynuując dalszych analiz wskazujących na konieczność istnienia jednostki poznawczej, należy przyjąć, iż prawdopodobnie taka jednostka rzeczywiście jest i posiada następujące cechy:

- integruje emocje i poznanie,

- uwzględnia wymiar czasu (a nie jedynie przestrzeni, czyli obrazu), który 
jest wskaźnikiem aktywności i pobudzenia (zwykle pomija się czas w procesach psychicznych, a jeśli się do niego odwołuje, to najczęściej dotyczy to psychomotoryki i reakcji na bodziec, czyli de facto nie bierze się pod uwagę podstawowej roli czasu w procesach psychicznych),

- łączy język z poznaniem i emocjami.

\section{PROPOZYCJA JEDNOSTKI POZNAWCZEJ}

Gdzie i jak szukać podstawowej jednostki poznawczej? Jak ją zdefiniować? Rozwiązanie powyższych dylematów oferuje matematyczna teoria komunikacji przedstawiona przez D. Gabora (1946, s. 429-457), a przede wszystkim wyprowadzona $\mathrm{z}$ niej podstawowa jednostka przetwarzania informacji określona mianem $\log о п и$ (rys. 1). Autor tej koncepcji uznał, że prawdopodobnie ma ona zastosowanie nie tylko do telekomunikacji, ale również do podstawowych jednostek przetwarzania informacji w układzie nerwowym. Dodatkowym argumentem przemawiającym za przyjęciem tej koncepcji jest stanowisko wybitnego neuropsychologa K. Pribrama (2013), który sugeruje, że odnosi się ona także do podstawowej jednostki przetwarzania informacji w mózgu, a psychologia powinna ją uwzględnić. W modelu Gabora zostały wyróżnione dwa podstawowe wymiary: czas i przestrzeń. Interesujące jest to, że pod względem formalnym wzór matematyczny logonu jest zaskakująco zbieżny z wzorem opisującym zasadę nieoznaczoności W. Heisenberga odnoszącą się do mikroświata. Jego formuła ma następującą postać:

$$
\Delta t \times \Delta f \approx 1,
$$

gdzie:

$\Delta t$ - prawdopodobieństwo czasu/pędu,

$\Delta f$ - prawdopodobieństwo częstotliwości/położenia,

$\Delta$ - szacunek, prawdopodobieństwo, estymacja, $t$ - czas (Gabor), pęd (Heisenberg),

$f$ - częstotliwość (Gabor), położenie (Heisenberg).

Jeśli mielibyśmy powyższą formułę/wzór przyjąć za opis podstawowej jednostki poznawczej, należałoby dokonać jej interpretacji, a właściwie translacji na zjawiska psychiczne. Czy jednak interpretacja przedstawionego wzoru w psychologii ma sens i czy prowadzi do obiecujących rezultatów?

Ostatecznie można stwierdzić, że istnienie tak rozumianej podstawowej jednostki informacyjnej w obszarze psychiki jest zasadne o tyle, o ile przetwarzanie informacji w układzie poznawczym obejmuje z jednej strony wymiar przestrzenny (obraz), a więc częstotliwość, a $\mathrm{z}$ drugiej proces ten przebiega w określonym czasie, ściśle związanym z pobudzeniem, czyli z siłą. W takim ujęciu $f$ z wzoru Gabora należałoby rozumieć jako obraz lub tzw. percept czy spostrzeżenie, a $t$ - jako czas jego 


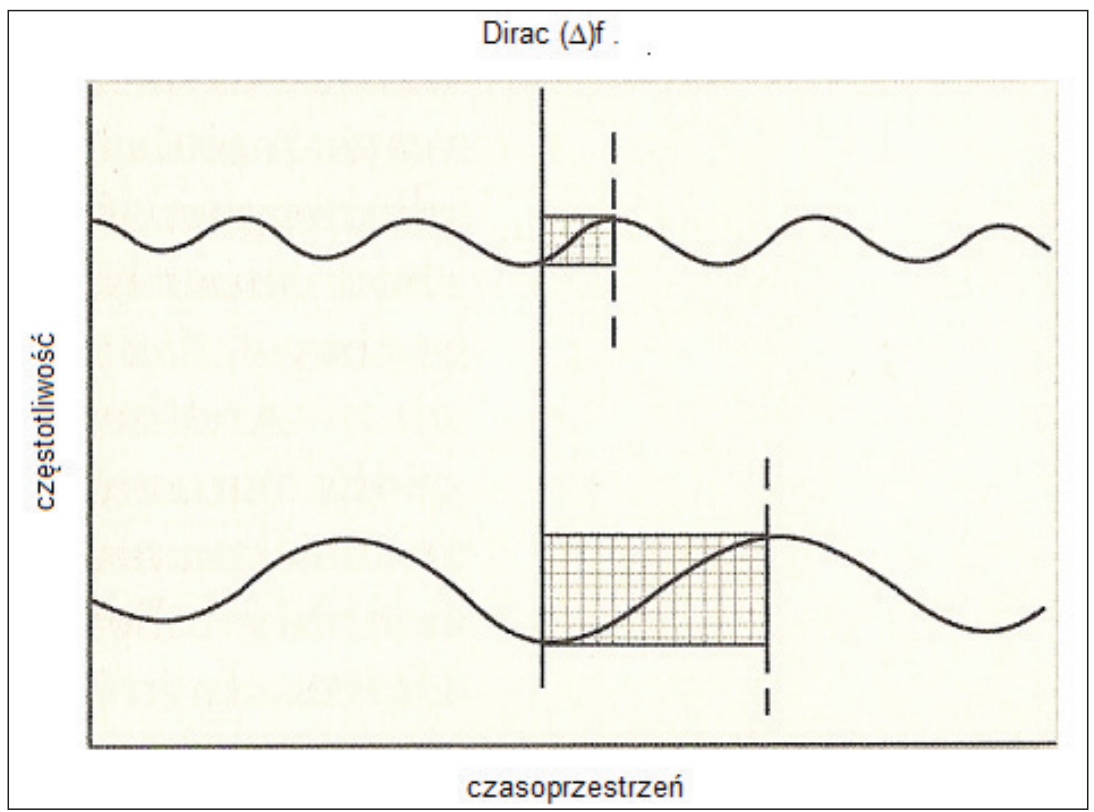

Rys. 1. Logony, czyli elementarne funkcje D. Gabora, będące kwantami informacji (zaznaczone jako prostokąty). Występują one na różnych poziomach (w różnych skalach), same mogą składać się z mniejszych logonów (małe kratki)

Źródło: opracowanie na podstawie: (Pribram 2013).

trwania, będący wyrazem siły pobudzenia, która w psychologii zawsze odnosi się do sfery emocjonalno-motywacyjnej. Inaczej mówiąc, interpretacja wzoru Gabora na gruncie psychologii oznacza, że $\Delta f$ to dokładność (prawdopodobieństwo, szacunek, stopień precyzji, adekwatność) spostrzeżenia (obrazu), natomiast $\Delta t$ to prawdopodobieństwo (wyrazistość, wariancja) obecności emocji (jako pobudzenia). Postać wzoru Gabora na gruncie psychologii może być więc zapisana następująco:

$\Delta$ emocja $\mathrm{x} \Delta$ poznanie $\approx 1$,

gdzie:

$\Delta$ - wariancja, precyzja, z jaką możemy określić emocje lub poznanie. Ta precyzja to tyle, co obecność i określenie danego wymiaru (emocji i obrazu) w „teraz”.

Tak zdefiniowaną jednostkę poznawczą należy rozumieć jako całość treściowo-emocjonalną, którą z perspektywy neuropsychologicznej można pojmować jako „dialogiczną” relację między korą i podkorą, postulowaną i opisaną przez J. LeDoux (2015).

Ważne jest również, aby zauważyć, że omawianą podstawową jednostkę przetwarzania informacji można interpretować z perspektywy informatycznej i fi- 
zycznej, czyli przyjmując punkt widzenia Gabora i Heisenberga. Każda z tych perspektyw ujmuje rzeczywistość z innego punktu widzenia (opisuje inny poziom rzeczywistości) i uwzględnia inny jej aspekt. Interpretacja Gabora dotyczy świata przetwarzania informacji, a interpretacja opracowana przez Heisenberga opisuje rzeczywistość z poziomu mikroświata, czyli zasady nieoznaczoności (tym samym zasada nieoznaczoności zostaje wprowadzona do psychologii).

Te dwie tak różne interpretacje mogą służyć do opisu ludzkiej psychiki. Zajmujący się holonomią (czyli holografią mózgu na poziomie kwantowym) Pribram uznał, że logon jako podstawowa jednostka przetwarzania informacji występująca w układzie nerwowym obejmuje też poziom kwantowy, dlatego postulował, aby psycholodzy - zamiast koncentrować się na szukaniu pojedynczych informacji w mózgu (bitów) - zajęli się całymi ich pakietami, czyli strukturami informatyczno-energetycznymi. Innymi słowy, analizując logon, brał pod uwagę zarówno jego interpretację poznawczą związaną z teorią komunikacji, jak i interpretację kwantową, obejmującą świat zasady nieoznaczoności według Heisenberga, nie widząc $w$ takim podejściu sprzeczności.

Niesprzeczność informatycznej i kwantowej interpretacji procesów poznawczych jest widoczna także w analizie psychiki jako zjawiska fizycznego rozpatrywanego w ramach teorii Heisenberga przez C.G. Junga i W. Pauliego (1970, s. 893-915). Próbowali oni wykazać, że relacje między świadomością a nieświadomością mają charakter komplementarny, co opisuje zasada nieokreśloności tożsama z wzorem Gabora. Mówiąc inaczej, rozważania tych autorów odnoszą się do fizyki kwantowej, do pędu cząstek fizycznych i popędu/instynktu w wymiarze psychologicznym oraz do treści informacji obecnych w świadomości, czyli do poznania. Należy zaznaczyć, że prace Junga i Pauliego, będące próbą wyjaśnienia procesów psychicznych opisywanych przez psychoanalizę w kategoriach fizyki kwantowej, powstały prawdopodobnie niezależnie od opracowań Gabora i Pribrama. Rozważania te łączy jedynie matematycznie opisana zasada nieoznaczoności przedstawiona w postaci wzoru Heisenberga, który tutaj występuje jako matematyczny opis podstawowej jednostki poznawczej. Wyniki analiz tych autorów sugerują, że omawiana formuła matematyczna ma uniwersalny charakter i opisuje rzeczywistość psychiczną z kwantowej i poznawczej perspektywy. Powstaje jednak pytanie, czego może dowodzić i na co może wskazywać opisana zbieżność omawianych wzorów? Gabor uważa, że należy podjąć poważną refleksję nad tym faktem i zdumiewa go, że jak dotąd nie doszło do przeprowadzenia dyskusji na ten temat.

\section{JEDNOSTKA POZNAWCZA (LOGON) JAKO POJĘCIE I JĘZYK}

Opisaną wzorem matematycznym dwuaspektową jednostkę poznawczą $(\approx 1)$ należy rozumieć jako całość składającą się z pobudzenia trwającego przez jakiś czas $(\Delta t)$ oraz z treści poznawczej $(\Delta f)$. Takimi jednostkami mogą być pojęcia emocjo- 
nalne (np. złość, miłość), złożone również z dwóch elementów składowych, którymi są pobudzenie i jego atrybucja, czyli jego reprezentacja pojęciowa. Tak rozumiane pojęcia emocjonalne mają wymiar energetyczno-treściowy, a wtedy czym innym jest pojęcie emocjonalne $(\approx 1)$, czym innym jego reprezentacja poznawcza $(\Delta f)$ i czym innym pobudzenie $(\Delta t)$, które zostało zinterpretowane za pomocą słowa $(\Delta f)$. Pobudzenie oraz jego interpretacja składają się zatem na pojęcie emocjonalne. (O tym, że istnieje pobudzenie jako realność i jego symbol/znak, czyli dwa aspekty pojęć, przekonuje uczenie się języka oraz nauka języków obcych, gdzie pobudzenie sensomotoryczne i poziom głęboki są zwykle podobne, a znak jako słowo, które je niejako „opakowuje” czy też konteneruje, w każdym języku jest inne.)

W psychologii poznawczej, mówiąc o pojęciach, ograniczamy się zwykle do sfery semantycznej $(\Delta f)$ i nie zajmujemy się ich podłożem energetycznym, czyli pobudzeniem $(\Delta t)$. W ten sposób pozostajemy jedynie w obszarze werbalnym i jego złożonej strukturze. W tej perspektywie, kiedy mówimy o pojęciach emocjonalnych, mamy na myśli formy reprezentacji, niejako pomijając to, co jest reprezentowane, co jest podłożem tej reprezentacji. Posługując się językiem A. Korzybskiego, skupiamy się na mapie, a nie na terytorium. Proponowana tu podstawowa jednostka poznawcza (logon), rozumiana np. jako pojęcie, obejmuje zarówno mapę (poznawczą reprezentację emocji), jak i terytorium (pobudzenie emocjonalne) $)^{1}$.

Te dwa wymiary, będące składowymi pojęć, można odnieść do dwóch rodzajów afazji: anomii i agnozji. W przypadku anomii osoba ma dostęp do pojęcia, potrafi je opisać lub odpowiednio kategoryzować, ale nie ma dostępu do jego nazwy (uszkodzony wymiar $\Delta f$ ), natomiast w agnozji semantycznej traci się dostęp do pojęć za pomocą percepcji wzrokowej, czyli za pomocą pobudzenia danego zmysłu (uszkodzony dostęp do doświadczenia obiektu, uszkodzony wymiar $\Delta t$ ), chyba że pozwolimy takiej osobie na dostęp do pobudzenia (do wymiaru $\Delta t$ ) za pomocą innego zmysłu, np. umożliwimy jej dotknięcie obiektu lub jego powąchanie. Zaburzenia te są w relacji antynomicznej, czyli dokładnie w takiej, jak dwa elementy podstawowej jednostki poznawczej (logonu). Takie rozumienie pojęć składających się z dwóch wymiarów można odnieść do ich neuroobrazowania za pomocą rezonansu magnetycznego (fMRI), wskazującego na rozproszoną i obejmującą wiele różnych obszarów korowych i podkorowych aktywność mózgu w czasie ich badania. Aktywność podkorową wiązałbym z czynnikiem pobudzenia $(\Delta t)$, a korową $-\mathrm{z}$ czynnikiem poznawczym $(\Delta f)$ pojęcia.

$Z$ drugiej strony należy zauważyć, że zarówno obszar reprezentacji $(\Delta f)$, jak i pobudzenia $(\Delta t)$ ma własną strukturę, tworzącą jedną spójną całość, czyli pojęcie rozumiane jako logon $(\approx 1)$. Tak powstałe pojęcie $(\operatorname{logon})$, mimo swojej

Podział ten można odnieść również do koncepcji T. Twardowskiego, który wyróżnił czynności $(\Delta t)$ i wytwory $(\Delta f)$. 
złożoności, jest na tyle spójne, że trudno je praktycznie rozdzielić, jest jednością i pełni funkcję podstawowego narzędzia komunikacji językowej. Jego wewnętrzna struktura to swoista struktura językowa. Można powiedzieć, że jest jednostką mikrojęzykową, która w rozbudowanej formie może zostać rozwinięta w zdanie. W tym ujęciu pojęcie to mikrozdanie.

Złożoność pojęć emocjonalnych (np. miłość, strach) na poziomie reprezentacji $(\Delta f)$ przedstawiła w swojej pracy B. Gawda (2017). Autorka podjęła się zbadania struktury poznawczej pojęć emocjonalnych, zaproponowała także jej model. Wyniki tych badań rzucają ciekawe światło na rozumienie omawianej jednostki poznawczej w wymiarze semantycznym $(\Delta f)$. Ponadto pozwalają stwierdzić, że z jednej strony złożoność pojęć emocjonalnych na poziomie reprezentacji ma charakter językowy, a z drugiej struktura tych pojęć jest (podobnie jak struktura logonu) dwuwymiarowa, czyli można wyróżnić w nich rdzeń i warstwę peryferyjną. Oznacza to, że na poziomie samej reprezentacji pojęć można wydzielić jednostki typu logon, mające dwuaspektową strukturę, mimo że reprezentacja pojęcia sama jest elementem składowym pojęcia jako logonu na poziomie energetyczno-treściowym. Wygląda na to, że logon na określonym poziomie sam jest zbudowany z logonów niższego rzędu, czyli podstawowa jednostka informacji ma podobną strukturę, ale na niższym poziomie. Gdyby zatem przyjąć, że logon jest złożoną podstawową jednostką językową, to mielibyśmy język w języku, strukturę w strukturze.

Należy w tym miejscu zauważyć, że podstawowa jednostka poznawcza ${ }^{2}$ może być rozumiana nie tylko jako pojęcie, ale także jako struktura językowa będąca zdaniem, gdzie jeden jego aspekt ma charakter czasowy, sekwencyjny, syntaktyczny, na wzór syntaktycznej struktury zdania $(\Delta t)$, a drugi ma charakter obrazowy, czyli treściowy, będący reprezentacją pojęciową $(\Delta f)$. Tym samym strukturę pojęcia można rozumieć jako mikrostrukturę, będącą składową zdania (z którego powstaje logon jako zdanie na wyższym poziomie). W takim ujęciu zdanie może być rozumiane jako rozwinięta struktura pojęcia, a pojęcie - jako mikrozdanie, czyli „zwinięte” zdanie. Idzie o to, że pojęcia i zdania mają podobną budowę (językową), tzn. budowę jednostki poznawczej, która wydaje się mieć uniwersalny charakter. To tak jakby logon i jego struktura mogły tworzyć zarówno zdanie, jak i słowo/pojęcie. Logon stanowiłby formalny fundament procesów poznania ${ }^{3}$. W tym miejscu twierdzenie L. Wittgensteina (1997, s. 64) zawarte w tezie 5.6. traktatu logiczno-filozoficznego, że „Granice mojego języka oznaczają granice mojego świata”, wydaje się jak najbardziej trafione.

Warto porównać również zbieżność struktury logonu ze składowymi trójkąta semantycznego, czyli nazwy jako logonu $(\approx 1)$, znaczenia jako treści poznawczej $(\Delta f)$ i desygnatu jako pobudzenia $(\Delta f)$.

W jakiej relacji logony są ze sobą i jak wygląda ich hierarchia, to sprawa organizacji mózgu i jego procesów. Organizacja ta może mieć charakter np. fraktali czy hologramu. 
Powyższa propozycja rozumienia pojęcia lub zdania jako logonu jest zgodna z ogólnymi rozwiązaniami binarnymi przyjętymi w językoznawstwie, które postulował wybitny badacz języka R. Jakobson (1989). Wartość rozpatrywania języka z punktu widzenia logonu, złożonego z wymiaru przestrzeni $(\Delta f)$ i czasu $(\Delta t)$, najlepiej wyraził w następujących słowach: „Czas i przestrzeń, które zwykle uważa się za zewnętrzne w stosunku do kodu języka, okazują się prawdziwymi jego składnikami” (Jakobson 1989, s. 44), a dalej: „Moje ciągle trwające badania nad afazją można podsumować: Podstawowe pojęcia binarne, które uznaje się w lingwistycznych poszukiwaniach za klucz do rozumienia oczywistej dychotomii zakłóceń afatycznych (...), wymagają pilnie głębszego i szerszego oglądu" (Jakobson 1989, s. 45). Mam nadzieję, że zaproponowana tu dwuaspektowa jednostka logonu, rozumiana jako struktura językowa, wychodzi naprzeciw stanowisku Jakobsona.

\section{WARTOŚĆ JEDNOSTKI POZNAWCZEJ (LOGONU) DLA PSYCHOLOGII}

\section{Wartość empiryczna}

Pierwszą rzeczą, na którą należy zwrócić uwagę, oceniając matematyczną formułę jednostki poznawczej, jest jej walor empiryczny, czyli możliwość eksperymentalnego sprawdzenia jej poprawności. Propozycja ta otwiera pole wielu interesującym badaniom, oczywiście po wcześniejszej operacjonalizacji dwóch wyróżnionych zmiennych składających się na omawianą jednostkę. Badania mogą dotyczyć obszaru emocji, poznania i języka, a ich modelem teoretycznym i niejako punktem orientacyjnym powinna być postulowana przez Gabora i Pribrama podstawowa jednostka poznawcza określona terminem logon.

\section{Regulacja, samoregulacja i punkt równowagi wewnętrznej}

Ważne jest to, by rozumieć jednostkę poznawczą jako dynamiczny układ równoważący się i samoregulujący. Regulacja, mająca miejsce w jej ramach, odbywa się między dwoma elementami składającymi się na nią (zasada nieoznaczoności jest wyznacznikiem regulacji). Ponadto struktura charakteryzująca się równowagą musi posiadać centralny punkt równowagi, który mógłby mieć zmienny charakter i raz znajdować się między emocjami a poznaniem, a innym razem przenieść się albo w obszar emocji, albo w obszar poznania (zależałoby to od wewnętrznej dynamiki tej jednostki, wynikającej z czynników wewnętrznych lub zewnętrznych). Punkt równowagi przeniesiony w obszar emocji przejawiałby się tzw. emocjonalizacją świadomości ${ }^{4}$, czyli byłby to stan, w którym emocje biorą górę nad pozna-

4 Termin ten, w ramach zaproponowanej koncepcji antropologicznej, wprowadził K. Wojtyła (1985, s. 68-71). Warto zauważyć, że opisywana tu jednostka przetwarzania informacji (logon), 
niem. W przypadku odwrotnym punkt środkowy (punkt równowagi) znajdowałby się w obszarze poznania i wiązałby się subiektywnie z nieobecnością emocji, jeśli jest to w ogóle możliwe (por. Perls 1981). Mielibyśmy w tych przypadkach kompensację poznania przez emocję lub odwrotnie, czyli kompensację emocji przez poznanie. W wymiarze fizjologicznym taka równowaga mogłaby odnosić się do komplementarności lub współpracy między półkulami mózgowymi, z których jedna odpowiedzialna jest bardziej za emocje, a druga za poznanie racjonalne.

Inaczej mówiąc, samoregulację jednostki poznawczej w ramach struktur mózgowych można rozumieć $\mathrm{z}$ jednej strony jako dialog między półkulami, a z drugiej jako dialog między korą a podkorą, co - jak wcześniej wspomniano - zasugerował LeDoux.

W podobnym duchu co do stałości jednostki poznawczej wypowiedział się R.R. Llinas (2011), który uważa, że tzw. powszechniki są kwantowane i posiadają tzw. punkt centralny, czyli cechują się wewnętrzną równowagą.

Warto w tym miejscu przyjąć rozumienie języka za Pribramem, który uznaje go za przejaw samoregulacji. Gdyby uznać tę koncepcję, to należałoby zaakceptować stanowisko, że samoregulująca się jednostka poznawcza (logon) jest innym opisem struktury języka i odwrotnie, tzn. język jest jednostką poznawczą, podobnie jak pojęcie, co zgodne jest z wcześniejszymi uwagami dotyczącymi języka jako synonimu jednostki poznawczej.

\section{Okno uwagowe}

Dla badań neurofizjologicznych (głównie dotyczących EEG) jest ważne, aby dokonać szerszej i głębszej interpretacji okna uwagowego. W stosunku do logonu wydaje się ono jednostką niepełną, gdyż obejmuje jedynie czas trwania $(t)$, natomiast nie uwzględnia dostatecznie dobrze treści $(f)$, jakiej dotyczy, oraz jej struktury. Inaczej mówiąc, pomija obraz, nie wspominając już o tym, że nie uwzględnia relacji elementów wchodzących w jego skład. Przedstawiona tu propozycja jednostki poznawczej pozwala na połączenie w ramach okna uwagowego parametrów czasowych z przestrzennymi (obrazem), które razem stanowią całość, mającą - zgodnie z wzorem Gabora-Heisenberga - przybliżoną wartość 1 . Eksperymentalnie można sprawdzić, na ile treść bodźca oraz parametry czasowe i strukturalne okna uwagowego obserwowane w EEG są ze sobą powiązane, tzn. czy parametry czasowe i przestrzenne odpowiadają matematycznej formule omawianej jednostki poznawczej i są w stosunku do siebie w takiej zależności, że dają wartość bliską 1, jak to wynika z wzoru definiującego logon.

ze względu na swoją dwuaspektowość, wpisuje się w szersze rozumienie człowieka przedstawione przez Wojtyłę (1985). 


\section{Teoria Gestalt jako jednostka poznawcza i zasada zachowania stałości}

Ze względu na to, że empiria jest sprawdzianem wartości, idąc dalej, można pokusić się o poszerzenie uniwersalności proponowanej tu jednostki i zbadać, czy można ją zastosować do innych antynomiczych zmiennych (mogących również mieć charakter przestrzeni $[\Delta f]$ i czasu $[\Delta t])$, np. do figury i tła składających się na poznawczą strukturę Gestalt. (Warto w tym miejscu podkreślić, że niezwykle ważny w języku jest także podział na figurę i tło, gdyż umożliwia rozpoznanie, co jest kontekstem w zdaniu, a co nie.) Czy zatem proponowana jednostka poznawcza wzbogaca teorię postaci o zasadę zachowania stałości, wymuszając relację wzajemnej kompensacji między jej dwiema składowymi, czyli między figura a ttem? Kompensacja immanentnie zawarta w jednostce poznania wynika z ograniczeń jej elementów przez wartość całej jednostki wynoszącej w przybliżeniu 1, co umożliwia ujawnienie potencjału tkwiącego w poszczególnych składowych struktury Gestalt. Takie ujęcie jednostki poznawczej otwiera nowe perspektywy badawcze, których dotychczasowe rozumienie teorii postaci nie posiada.W tradycyjnej koncepcji Gestalt pole percepcyjne składa się z figury i tta, a granica między nimi dzieli rzeczywistość na dwa obszary. Poza ich wzajemnym oddziaływaniem na siebie nie ma żadnej innej zasady, która wyznaczałaby granice tym zmiennym, tzn. nie ma trzeciej siły wpływającej na nie jednocześnie, ograniczającej je. W odróżnieniu od tak rozumianej teorii postaci niniejsza propozycja logonu, w ramach której dwiema jej składowymi mogą być figura i tło, wprowadza trzecie ograniczenie - jest nim zasada zachowania stałości całego pola poznawczego (tożsama z zasadą nieoznaczoności), która ma łączną wartość wynoszącą $\approx 1$. Zasada ta wyznacza ograniczenia zarówno dla figury, jak i dla tła, tzn. określa ich ramy, czyli zarysowuje warunki samoregulacji i ich równoważących się oddziaływań. Pod wpływem zmian zachodzących w poszczególnych jej elementach dochodzi do wzajemnej kompensacji. Koncepcja Gestalt, rozumiana jako logon, w ramach której dwoma czynnikami są figura i tło, zyskuje więc status układu równoważącego się oraz samoregulującego się, przybierając następującą postać: $\Delta$ figura $\mathrm{x} \Delta$ tło $\approx 1$.

\section{Równoważenie jednostki poznawczej a koncepcja J. Piageta}

Kiedy wysuwa się tak ogólną propozycję, jak w niniejszej pracy, a jednocześnie tak konkretną i przekładalną na empirię, powstaje pytanie o dotychczasowe koncepcje struktur poznawczych w psychologii. Najbardziej rozbudowaną i dobrze ugruntowaną teorią, do której należy się odnieść, jest koncepcja J. Piageta. Autor ten przyjął, iż rozwój struktur poznawczych to przechodzenie od niedoskonałych form równowagi do form „lepszych”, co związane jest z takimi operacjami umysłowymi, jak odwrotność, wzajemność czy kompensacja. W celu wyja- 
śnienia, dlaczego osiągnięcie zwykłej czy doraźnej równowagi poznawczej nie kończy procesu rozwoju poznawczego (czyli dlaczego ona nie wystarcza), Piaget wprowadził pojęcie ,równoważenia majoryzującego”, podkreślając, że „W rzeczywistości system nie stanowi nigdy absolutnego kresu procesów równoważenia, a z osiągniętej już równowagi chwiejnej, czy nawet stabilnej, powstają zawsze nowe cele (...)" (Piaget 1981, s. 36). W zasadzie badacz stanął przed problemem, z którym wcześniej nie poradziła sobie teoria postaci (Gestalt), i rozwiązał go poprzez wprowadzenie nowego pojęcia. Zdawał sobie sprawę z faktu, że musi istnieć dodatkowy i niejako nadrzędny autonomiczny czynnik odpowiedzialny za równoważenie poznawcze, który $\mathrm{z}$ jednej strony zmusza do ciągłego równoważenia, a z drugiej generuje takie operacje, jak kompensacja czy odwracalność. Jak sam zauważył: „(...) równowaga biologiczna jest autoregulacją i systemy autoregulacyjne dostarczają mechanicznych ekwiwalentów celowości (...)" (Piaget 1967, s. 200). W rzeczywistości procesy równoważenia są możliwe jedynie wtedy, gdy istnieje czynnik ograniczający całość struktury poznawczej i jej cele (autoregulacja), czyli kiedy jej elementy funkcjonują w ramach pewnych granic, w ramach całości, która wywiera presję na równoważące się składowe, czyli de facto wtedy, kiedy są elementami jednostki poznawczej.

W świetle niniejszych rozważań można zaryzykować stwierdzenie, że równoważenie majoryzujące jest konsekwencją istnienia podstawowej jednostki poznawczej $^{5}$ określonej wzorem Gabora-Heinsenberga. To jednostka poznawcza wyznacza procesy równoważenia i jest odpowiedzialna za przyjęty przez Piageta proces majoryzacji. Ramy, w których następuje równoważenie, są zatem określone przez zasadę nieoznaczoności obecną w wymiarze poznawczym, czyli przez logon. Wydaje się interesujące przeanalizowanie teorii Piageta z perspektywy jednostki poznawczej. Niewykluczone, że w ten sposób osiągnięcia psychologii genetycznej zyskają nową interpretację i pogłębią dotychczasowe rozumienie dynamiki procesów poznawczych.

\section{Uniwersalizm jednostki poznawczej}

Wartością omawianej jednostki poznawczej jest również jej uniwersalizm, który swoim zasięgiem dorównuje znanej metaforze zaproponowanej przez Korzybskiego (1994), opisującej rzeczywistość jako dychotomię mapy i tła, a która zdaje się nowożytnym wariantem Arystotelesowskiej formy i materii. Sugerowana tu uniwersalność jednostki poznawczej jest wysoce niepokojąca, zwłaszcza że mapę i terytorium także można rozumieć jako jednostkę poznawczą składającą się

Jej dwoma elementami jako logonu mogą być wyróżnione przez Piageta asymilacja i akomodacja, jak również treść i forma, które próbował przedstawić jako zmienne ogólne w pracy Równoważenie struktur poznawczych (1981, s. 147-153). 
z przestrzeni jako synonimu mapy oraz z czasu jako synonimu terytorium. Niezależnie jednak od niepokoju i podejrzeń, jakie budzą zbyt uniwersalne propozycje (a może właśnie dlatego), warto zmierzyć się z nimi i sprawdzić empirycznie ich prawdziwość oraz granice ewentualnej stosowalności.

\section{KONCEPCJA F. CRICKA JAKO PODSUMOWANIE}

Zgodnie z powyższymi rozważaniami można stwierdzić, że omawiana podstawowa jednostka poznawcza (logon), opisana wzorem matematycznym Gabora-Heisenberga, pasuje do jednostki, której istnienie na poziomie neurofizjologicznym zaproponował laureat Nagrody Nobla F. Crick w książce pt. Zdumiewająca hipoteza. Opisał ją w sposób następujący:

Jednostka przetwarzająca (z których tylko część ma związek ze świadomością) to zbiór pól kory mózgowej położonych na tym samym poziomie hierarchii układu wzrokowego, które wysyłają sobie wzajemnie sygnały do warstwy 4 [korowy element poznawczy logonu $(\Delta f)-$ M.H.]. Każdy taki zbiór ma ścisły związek z dokładnie jednym małym obszarem wzgórza [emocjonalny element logonu $(\Delta t)-$ M.H.]. Obszar ten [układ, jednostka, logon - M.H.] koordynuje aktywność związanych z nim pól kory mózgowej, synchronizując ich wyładowania. (Crick 1997, s. 333-334).

Inaczej mówiąc, logon byłby matematycznym opisem jednostki przetwarzania zaproponowanej przez Cricka, która składa się ze składnika poznawczego (kora) oraz emocjonalnego (wzgórze).

\section{BIBLIOGRAFIA}

Crick, F. (1997). Zdumiewająca hipoteza. Warszawa: Prószyński i S-ka.

Gawda, B. (2017). Struktura pojęć emocjonalnych. Wykorzystanie technik fluencji werbalnej. Lublin: Wydawnictwo UMCS.

Gabor, D. (1946). Theory of communication. The Journal of the Institute of Electrical Engineers, 13, 429-457.

Jakobson, R. (1989). W poszukiwaniu istoty języka. Warszawa: PIW.

Jung, C.G., Pauli, W. (1970). Dwugłos o „korzeniach świadomości”. Znak, (7-8), 893-915.

Korzybski, A. (1994). Science and Sanity. An Introduction to Non-Aristotelian Systems and General Semantics. New Jersey: Institute of General Semantics.

LeDoux, J. (2015). Lęk. Neuronauka na tropie źródet lęku i strachu. Kraków: Copernicus Center Press.

Llinas, R.R. (2011). I of the Vortex. From Neurons to Self. A Bradford Book. Cambridge-Massachusetts-London: MIT. 
Miller, G.A., Galanter, E., Pribram, K.H. (1980). Plany i struktura zachowania. Warszawa: PWN.

Perls, F. (1981). Cztery wykłady. W: K. Jankowski (red.), Psychologia w działaniu (s. 156-193). Warszawa: Czytelnik.

Piaget, J. (1967). Mądrość i złudzenia filozofii. Warszawa: Instytut Wydawniczy Pax.

Piaget, J. (1981). Równoważenie struktur poznawczych. Warszawa: PWN.

Pöppel, E. (1989). Granice świadomości. Warszawa: PIW.

Pöppel, E., Edingshaus, A.L. (1998). Mózg - tajemniczy kosmos. Warszawa: PIW.

Pribram, K. (2013). The Form Within. My Point of View. Westport: Prospecta Press.

Senderecka, M. (2016). Analiza potencjałów zdarzeniowych i jej zastosowanie w badaniach nad uwagą selektywną. W: J. Bremer (red.), Przewodnik po kognitywistyce (s. 391-411). Kraków: Wydawnictwo WAM.

Wittgenstein, L. (1997). Tractatus Logico-Philosophicus. Warszawa: PWN.

Wojtyła, K. (1985). Osoba i czyn. Kraków: Polskie Towarzystwo Teologiczne.

\section{SUMMARY}

The question of the existence of a cognitive unit that integrates basic psychological processes, that is: cognition, emotions, and language, is raised in this paper. Usage of the concept of a basic unit of information processing (logon) in the form of a mathematical formula developed by D. Gabor in psychology is proposed here. It is inspired by views of K. Pribram and R. Llinas. Arguments for the existence of this unit in human psyche are presented, and its value for psychology is discussed here with reference to the concept of attention window, Gestalt, as well as J. Piaget's cognitive equilibrium.

Keywords: cognitive unit; logon; cognition; emotions; language; attention window; cognitive equilibrium; theory of communication 